Article

\title{
Monitoring and Assessment of Salinity and Chemicals in Agricultural Lands by a Remote Sensing Technique and Soil Moisture with Chemical Index Models
}

\author{
Hashim Ali Hasab ${ }^{1}$, Hayder Dibs ${ }^{2} @$, Abdulameer Sulaiman Dawood ${ }^{3}$, Wurood Hasan Hadi ${ }^{4}$, \\ Hussain M. Hussain ${ }^{4}$ (D) and Nadhir Al-Ansari ${ }^{5, *(D)}$ \\ 1 Al-Najaf Technical Institute, Department of Architectural Design and Decoration, Al-Furat Al-Awsat \\ Technical University, Najaf 54001, Iraq; hasab.hashim1979@gmail.com or hashim@atu.edu.iq \\ 2 Water Resources Faculty, Department of Hydraulic Structures Engineering, Al-Qasim Green University, \\ Babel 51001, Iraq; Dr.hayderdibs@wrec.uoqasim.edu.iq \\ 3 Al-Kufa Technical Institute, Al-Furat Al-Awsat Technical University, Kufa 54001, Iraq; kin.abd7@atu.edu.iq \\ or abdulameer.1957@yahoo.com \\ 4 Remote Sensing Center, University of Kufa, Kufa 54001, Iraq; wurodhasan84@gmail.com (W.H.H.); \\ hussainm.alshimmary@uokufa.edu.iq (H.M.H.) \\ 5 Department of Civil, Environmental and Natural Resources Engineering, Lulea University of Technology, \\ 97187 Lulea, Sweden \\ * Correspondence: nadhir.alansari@ltu.se; Tel.: +46-920491858
}

Received: 18 April 2020; Accepted: 19 May 2020; Published: 29 May 2020

check for updates

\begin{abstract}
Agricultural land in the south of Iraq provides habitat for several types of living creatures. This land has a significant impact on the ecosystem. The agricultural land of Al-Hawizeh marsh covers an area of more than $3500 \mathrm{~km}^{2}$ and is considered an enriched resource to produce several harvests. A total of $74 \%$ of this area suffers from a high degree of salinity and chemical pollution, which needs to be remedied. Several human-made activities and post-war-related events have caused radical deterioration in soil quality in the agricultural land. The goal of this research was to integrate mathematical models, remote sensing data, and GIS to provide a powerful tool to predict, assess, monitor, manage, and map the salinity and chemical parameters of iron (Fe), lead $(\mathrm{Pb})$, copper $(\mathrm{Cu})$, chromium ( $\mathrm{Cr}$ ), and zinc $(\mathrm{Zn})$ in the soils of agricultural land in Al-Hawizeh marsh in southern Iraq during the four seasons of 2017. The mathematical model consists of four parts. The first depends on the B6 and B11 bands of Landsat-8, to calculate the soil moisture index (SMI). The second is the salinity equation (SE), which depends on the SMI result to retrieve the salinity values from Landsat- 8 images. The third part depends on the B6 and B7 bands of Landsat- 8 , which calculates the clay chemical index (CCIs). The fourth part is the chemical equation (CE), which depends on the $\mathrm{CCI}$ to retrieve the chemical values $(\mathrm{Fe}, \mathrm{Pb}, \mathrm{Cu}, \mathrm{Cr}$, and $\mathrm{Zn}$ ) from Landsat- 8 images. The average salinity concentrations during autumn, summer, spring, and winter were 1175, 1010, 1105, and 1789 $\mathrm{mg} / \mathrm{dm}^{3}$, respectively. The average Fe concentrations during autumn, summer, spring and winter were 813, 784, 842, and $1106 \mathrm{mg} / \mathrm{dm}^{3}$, respectively. The average $\mathrm{Pb}$ concentrations during autumn, summer, spring, and winter were $4.85,3.79,4.74$, and $7.2 \mathrm{mg} / \mathrm{dm}^{3}$, respectively. The average $\mathrm{Cu}$ concentrations during autumn, summer, spring, and winter were 3.9, 3.1, 4.45, and $7.5 \mathrm{mg} / \mathrm{dm}^{3}$, respectively. The average $\mathrm{Cr}$ concentrations during autumn, summer, spring, and winter seasons were $1.28,0.73,1.03$, and $2.91 \mathrm{mg} / \mathrm{dm}^{3}$, respectively. Finally, the average $\mathrm{Zn}$ concentrations during autumn, summer, spring, and winter were $8.25,6,7.05$, and $12 \mathrm{mg} / \mathrm{dm}^{3}$, respectively. The results show that the concentrations of salinity and chemicals decreased in the summer and increased in the winter. The decision tree (DT) classification depended on the output results for salinity and chemicals for both SE and CE equations. This classification refers to all the parameters simultaneously in one stage. The output of DT classification results can display all the soil quality parameters (salinity, $\mathrm{Fe}, \mathrm{Pb}, \mathrm{Cu}$,
\end{abstract}


$\mathrm{Cr}$, and $\mathrm{Zn}$ ) in one image. This approach was repeated for each season in this study. In conclusion, the developed systematic and generic approach may constitute a basis for determining soil quality parameters in agricultural land worldwide.

Keywords: salinity; chemicals; mathematical models; remote sensing data; GIS

\section{Introduction}

The factors that pose a serious threat to ecosystems, water resources, and agricultural land include environmentally destructive development, human non-ethical activities, soil pollution, and inadequate discharge of sewage and industrial wastewaters [1,2]. The surface soil quality of agricultural land and watersheds—-such as marshes, lakes, and reservoirs—often varies depending on natural hydrological, biological, chemical, morphological, and sedimentation processes. Salinity, chemicals, heavy metals, and pathogens such as parasites, bacteria, and viruses present in waste materials constitute the most dangerous environmental pollutants [2-9]. Globally, approximately 25,000 deaths occur daily due to diseases related to pollution $[10,11]$. The huge agricultural area of southern Iraq have a significant impact on the ecosystem. This area is considered an enriched resource for the production of several crops such as rice, wheat, barley, and fruits. However, $74 \%$ of the land suffers from problems associated with salinity, chemicals, industrial activities, and toxic metals from the wars of previous decades, which combined have had a significant effect on the soil quality [12-17]. In the past few decades, the agricultural land of southern Iraq has suffered from sewage and industrial wastewater discharge, a lack of integrated agricultural land management, and poor public awareness for agricultural protection [18-20].

An integrated model using remote sensing data and a geographic information system (GIS) can provide a powerful tool for the development of a management processes to assess soil quality and soil surface pollution associated with the agricultural land [21-24]. A general total suspended of normalized difference vegetation index (Ts-NDVI) using vegetation indices from remote sensing data—such as Moderate Resolution Imaging Spectroradiometer (MODIS) and Advanced Very-High Resolution Radiometer (AVHRR) - was developed to monitor soil moisture in the Mongolian Plateau during the period 1981-2012 [25-29]. Soil moisture plays an important role in the hydrological process and is closely related to surface soil temperature at the same soil of the diurnal change. There was a stronger correlation between surface soil moisture (SSM) and surface soil temperature (SST) in two catchments, one in Australia and the other in the United Kingdom [30]. Landsat satellite images and GIS were used to map, monitor, assess, and detect change of wetland dynamics on the Chennai coast in India during three periods (1988-1996, 1996-2006, and 2006-2016) based on the supervised classification method [31-33].

Research has been carried out regarding the monitoring and management strategies of agricultural soils to reduce metal pollution by investigating heavy mineral contamination of $\mathrm{Cu}$, $\mathrm{Ni}, \mathrm{Co}, \mathrm{Cr}, \mathrm{Mn}$, and $\mathrm{Pb}$ in agricultural soil of the copper mining regions in India. In addition, researchers have used the enrichment factor, contamination factors, the Nemerow index, pollution loads index, geo-accumulation index, ecological risk index, and inductively coupled plasma-mass spectrometry (ICP-MS, Perkin Elmer DRC-e, Waitham, MA, USA) to determine the concentration of minerals and assess pollution levels in Singhbhum, India [25,34]. An analytical hierarchy process and a geographic information system was used to improve the sustainability and management of agricultural activity by evaluating six soil quality indicators-including $\mathrm{pH}$, cation exchange capacity (CEC), organic carbon (OC) and salinity-in the agricultural area of the Tadla Plain, Morocco. An analytical hierarchy process was also used to identify the weight of each soil quality indicator via a pair-wise comparison matrix and GIS was used to generate a soil quality environmental map [35]. 
GIS and multi-temporal remote sensing data, such as Landsat 5 Thematic Mapper (TM) and Landsat 7 Enhanced Thematic Mapper (ETM) satellite images, have been used to analyze vegetation stress to develop soil salinity maps and determine the content of total dissolved solids (TDS), total suspended solids (TSS), $\mathrm{Ca}, \mathrm{Mg}, \mathrm{Na}, \mathrm{K}, \mathrm{CO}^{3}, \mathrm{H} \mathrm{CO}^{3}, \mathrm{Cl}, \mathrm{NO}^{3}$, and $\mathrm{SO}^{4}$ in irrigated areas of Syrdarya province, Uzbekistan, with a higher degree of spatial accuracy and in a cost effective way [36]. Another study estimated soil salinity and conducted salinity mapping with considerable accuracy using multi-spectral remote sensing data with an advanced land imager (ALI) sensor and partial least-square regression model (PLSR), together with soil salinity data collected from the Yellow River Delta in China [37]. Another study used different satellite sensors (e.g., TM, MSS, ETM+, SPOT, Terra-ASTER, LISS-III, and IKONOS) and methods used to detect, monitor and map of soil salinity in arid and semi-arid regions [38]. Other studies assessed the metal contamination (As, $\mathrm{Cr}, \mathrm{Cd}, \mathrm{Co}, \mathrm{Fe}, \mathrm{Cu}, \mathrm{Zn}, \mathrm{Hg}, \mathrm{Pb}$, and $\mathrm{Mn}$ ) of sediments in the Shadegan and Hawr Al-Azim wetlands in southwestern Iran based on GIS and remote sensing with mathematical models [39-41].

This article critically evaluates the existing literature that indicate more studies are needed to bridge the gaps identified in previous studies. A comprehensive survey of the literature revealed that only a few techniques have been developed for the detection and monitoring of physical and chemical soil quality parameters in the marshland area of Iraq. More systematic studies are required to support findings from previous studies and improve the accuracy of findings on the soil of agricultural land. The aim of this research was to examine whether the integration between mathematical models, remote sensing Landsat-8 OLI data and GIS could provide a powerful tool for predicting, assessing, monitoring, managing, and mapping salinity and chemical parameters such as iron $(\mathrm{Fe}), \mathrm{lead}(\mathrm{Pb})$, chromium $(\mathrm{Cr})$, and copper $(\mathrm{Cu})$ in the soils of agricultural land in the Al-Hawizeh marsh in southern Iraq during the four seasons of 2017.

\section{Study Area}

The study area was the agricultural land that surrounds Al-Hawizeh marsh in southern Iraq, covering an area of 3500-4000 km², as shown in Figure 1. It is considered an enriched resource for the production of several crops that have a significant impact on the ecosystem, as well as a habitat for biodiversity $[13,14,18]$. The neglect and wars of recent years are factors that have led to an increase of salinity and heavy chemical pollution in this area. Al-Hawizeh marsh is the major water source for these lands $[15,16,18,20]$.

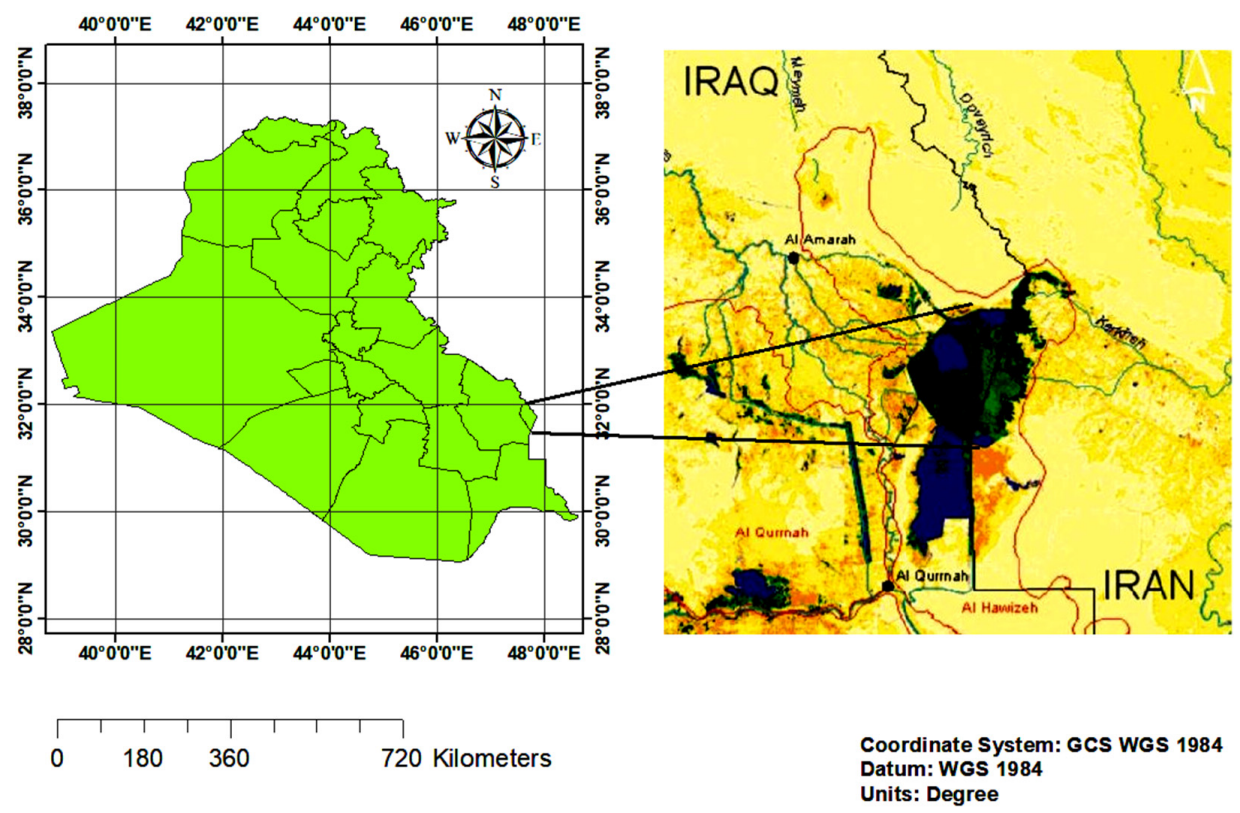

Figure 1. Geographical location of the study area. 


\section{Methodology}

The methodology adopted for this article is presented as a flowchart in Figure 2. It includes details regarding satellite images, image pre-processing, soil samples, soil analysis, mathematical models, data validation, image classification, and data visualization. Landsat- 8 satellite images are represented as basic remote sensing data collected during 2017. Processed images from Landsat- 8 satellite data and ancillary data were synergistically integrated with the mathematical models to predict the salinity and concentrations of chemicals $(\mathrm{Fe}, \mathrm{Pb}, \mathrm{Cu}, \mathrm{Cr}$, and $\mathrm{Zn})$ in the soil for the agricultural land of the study area. The creation of mathematical models was informed by the nature of the satellite image processing and auxiliary data. The mathematical models had two equations: salinity equation (SE) and chemical equation (CE). The SE was based on the soil moisture index (SMI), which depends on the B6 and B11 bands. The CE was based on the clay chemical indices (CCIs), which depends on the B6 and B7 bands. The outputs of both salinity and chemical equations were the salinity and chemical concentration data obtained from the spatial distribution of satellite images. These data were categorized using a decision tree (DT) of image classification to classify the salinity and chemical parameters on satellite images over four seasons. Data visualization was used to check the salinity, $\mathrm{Fe}, \mathrm{Pb}, \mathrm{Cu}, \mathrm{Cr}$, and $\mathrm{Zn}$ classification results on the maps with the appropriate specifications as output results of data validations.

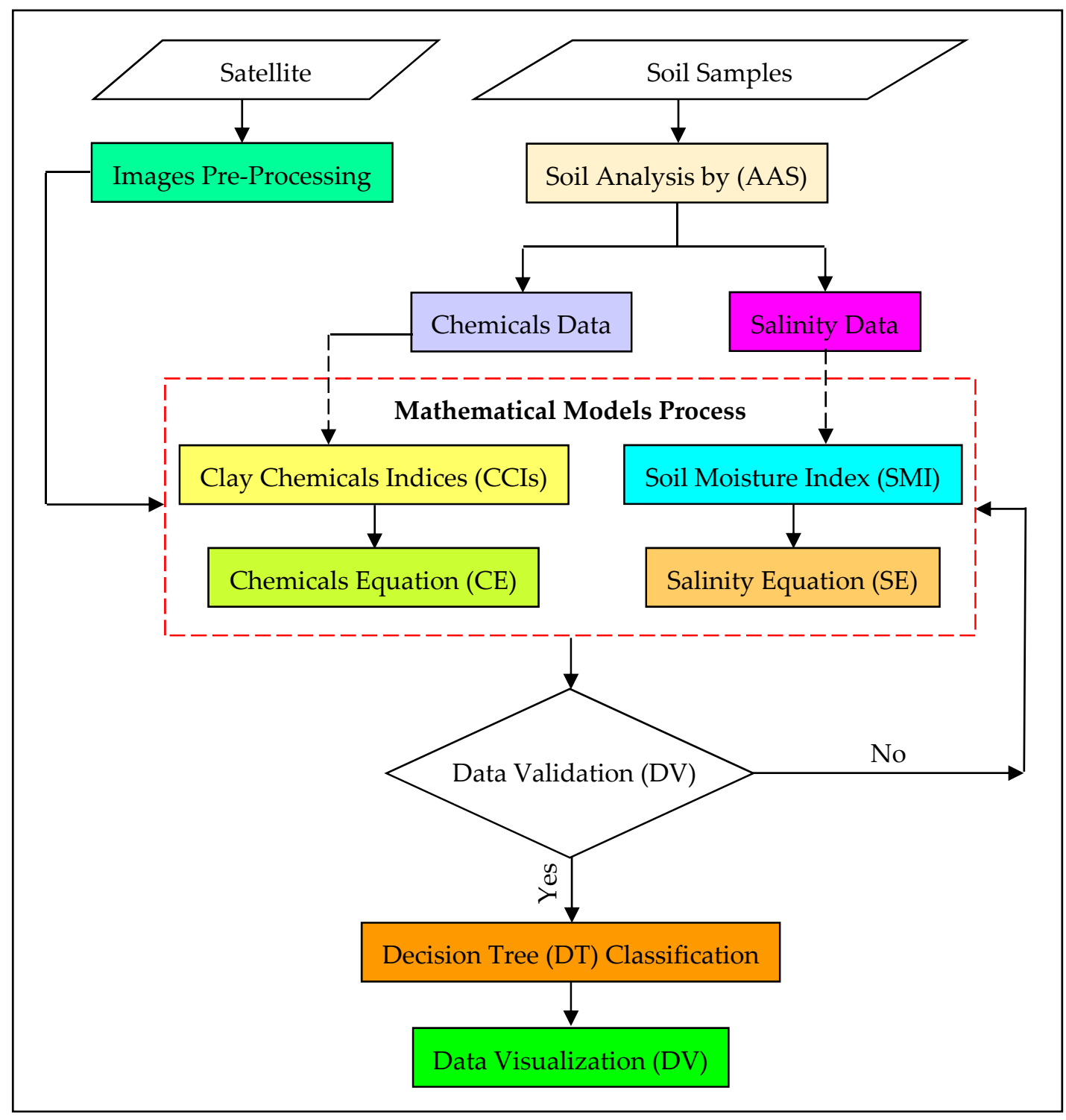

Figure 2. Flowchart of research methodology. 


\subsection{Satellite Images and Pre-Processsing}

The remote sensing data used satellite images from Landsat- 8 OLI at longitude $47^{\circ} 32^{\prime \prime}-47^{\circ} 45^{\prime \prime} \mathrm{E}$ and latitude $31^{\circ} 30^{\prime \prime}-31^{\circ} 42^{\prime \prime} \mathrm{N}$ with a resolution of $30 \mathrm{~m}$. The satellite images of the study area were synchronized with soil samples collected from the agricultural land during 2017. The mathematical models of this study were based on the B6, B7 and B11 bands of the satellite image, as shown in Table 1. Accurate pre-processing of Landsat- 8 satellite images, including atmospheric correction, is the first important step of the research methodology. This process involves radiometric calibration, dark subtraction, and internal average reflectance (IAR) calibration, layer stacking, georeferencing, image enhancement, and region of interest (ROI) determination. The output of this process provides suitable images. These data were combined with mathematical models for assessing and monitoring the spatial distribution of salinity and chemicals in the study area.

Table 1. Endowment of Landsat-8 (OLI and TIRS) band details [42,43]

\begin{tabular}{lcc}
\hline \multicolumn{1}{c}{ Band } & Wavelength & Useful for Mapping \\
\hline Band 6-Short-wave Infrared (SWIR) 1 & $1.57-1.65$ & $\begin{array}{c}\text { Discriminates moisture content of soil } \\
\text { and vegetation; penetrates thin clouds } \\
\text { Improved moisture content of soil and vegetation } \\
\text { and thin cloud penetration }\end{array}$ \\
Band 7-Short-wave Infrared (SWIR) 2 & $2.11-2.29$ & \begin{tabular}{c} 
100 $\begin{array}{c}\text { m resolution. Improved thermal mapping } \\
\text { and estimated soil moisture }\end{array}$ \\
\hline
\end{tabular} \\
\hline
\end{tabular}

\subsection{Soil Sample Collection}

Soil samples were collected at $15 \mathrm{~cm}$ depth using a clean shovel. These samples were collected from 60 stations positioned across different regions, covering the whole of the agricultural land by using the Global Positioning System (GPS). These soil sampling stations were numbered S1-S60, as illustrated in Figure 3. All soil samples underwent laboratory testing using the atomic absorption spectrophotometer (AAS) technique to measure the concentration values for salinity and chemicals $(\mathrm{Fe}, \mathrm{Pb}, \mathrm{Cu}, \mathrm{Cr}$, and $\mathrm{Zn})$. These data were used to determine the status of soil quality.

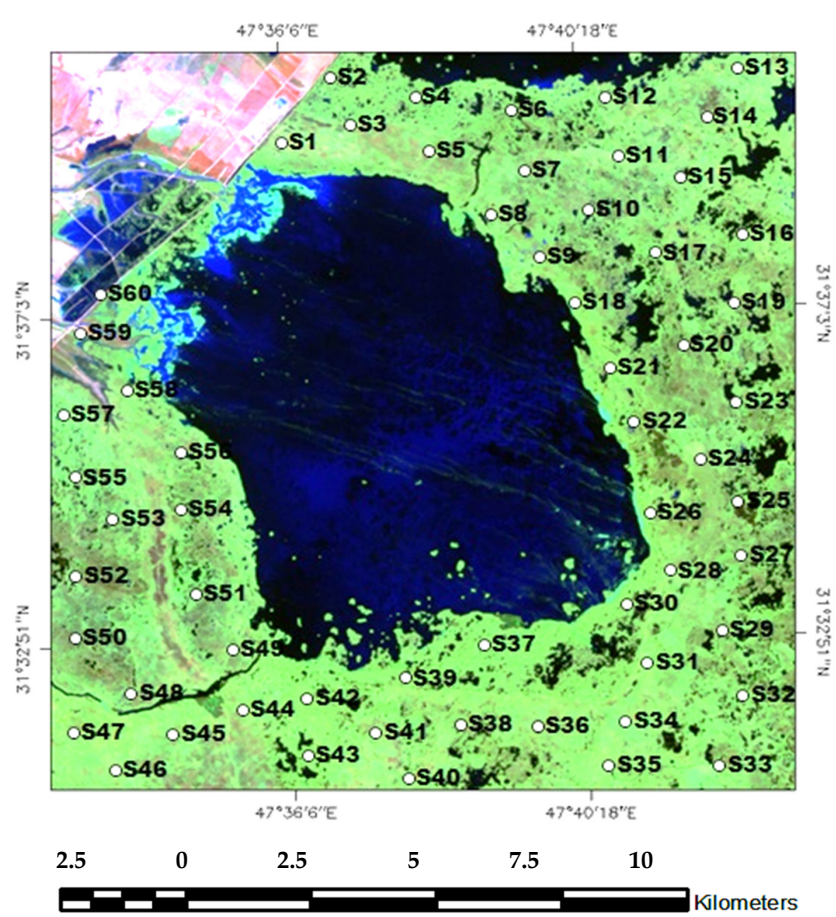

Figure 3. Satellite image showing the soil sampling stations. 


\subsection{Analysis of Soil Samples}

Soil types present in Iraq are Alfisol (5\%), Mollisol (5\%), Vertisol (10\%), Inceptisol (15\%), Entisol $(20 \%)$, and Aridisol (45\%). The soils in the agricultural area of Al-Hawizeh marsh are dominated by relatively fertile alluvial soils within the Entisol soil order based on the classification scheme of the United States for Iraq soils from 1965 [44-47].

All data were tested using the atomic absorption spectrophotometer (AAS) technique. AAS is a technique used to measure trace elements present in soil samples, in which free gaseous atoms absorb electromagnetic radiation at a specific wavelength to produce a measurable signal. The absorption signal is proportional to the concentration of those free absorbing atoms in the optical path. Therefore, for AAS measurements, the sample must be converted into gaseous atoms, usually by the application of heat to a cell using an atomizer. The main type of atomizer used in AAS-based analytical techniques is the flame AAS (FAAS), which provides analytical signals in a continuous fashion [48,49].

The samples were grinded in a motor and sieved. Using $1 \mathrm{~mm}$, the sample $(1 \mathrm{~g})$ was digested with concentrated nitric acid in a sand bath until dry. Then, deionized water was added and the sample was filtered then complete the filtrate to $25 \mathrm{~mL}$ with deionizer water. AAS was used to determine the chemical concentrations at specific wavelengths along with a hallow cathode lamp (HCL). Chemical speciation was determined by AAS after extraction of the metal with different chemical reagents.

The soil analysis results for the salinity and chemicals represent the real data, demonstrating the status of the soil quality in the agricultural land. The concentration values for the salinity and the chemicals during four seasons were lowest in the summer and highest in the winter, as shown in Figures 4 and 5. The minimum, maximum, and average of salinity and chemicals during the four seasons are shown in Table 2. The mathematical models used these data to combine with satellite images and assess the salinity and chemical values for the four seasons of 2017.

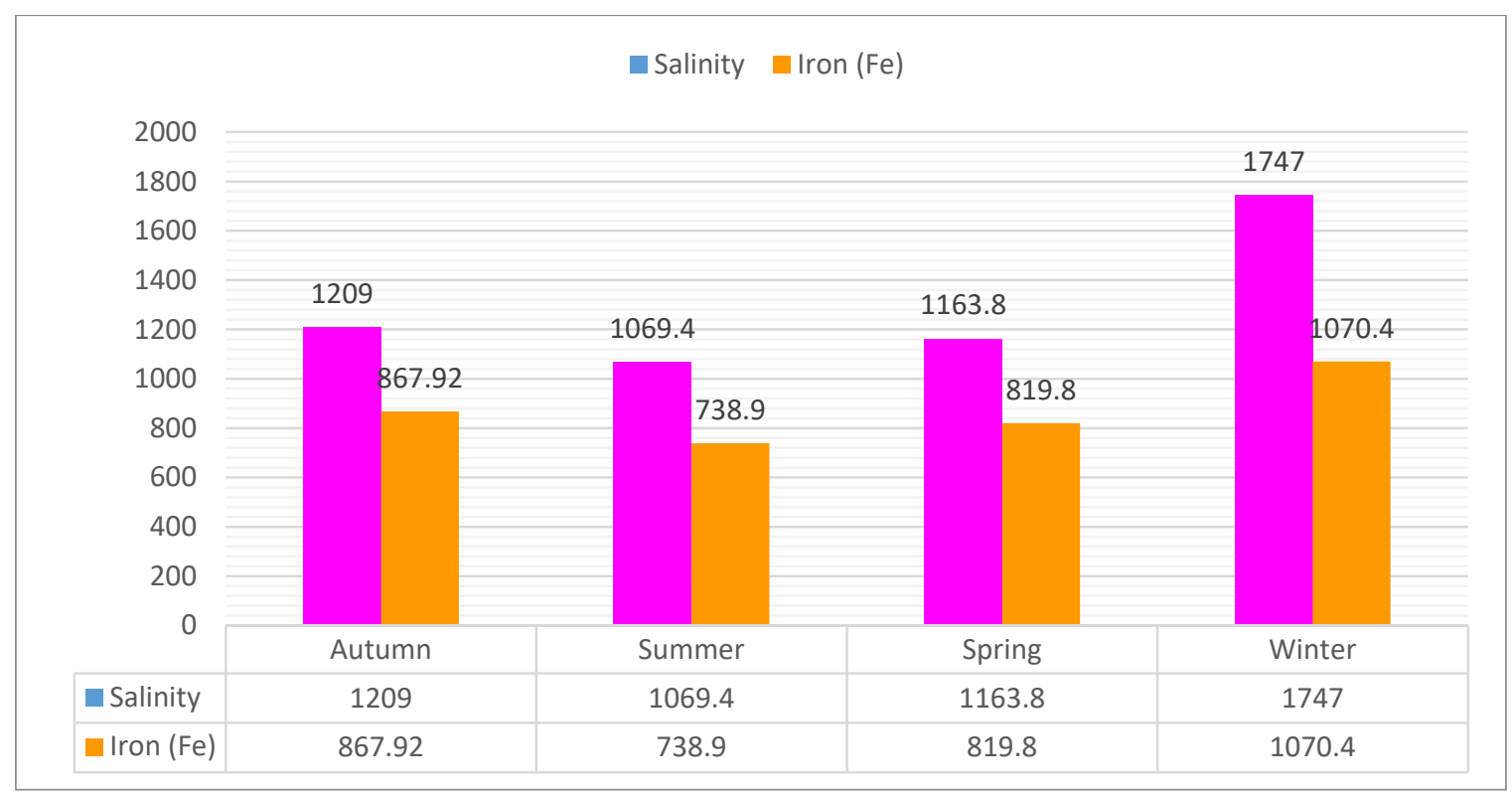

Figure 4. Laboratory measurements for the four seasons of 2017, salinity and iron. 


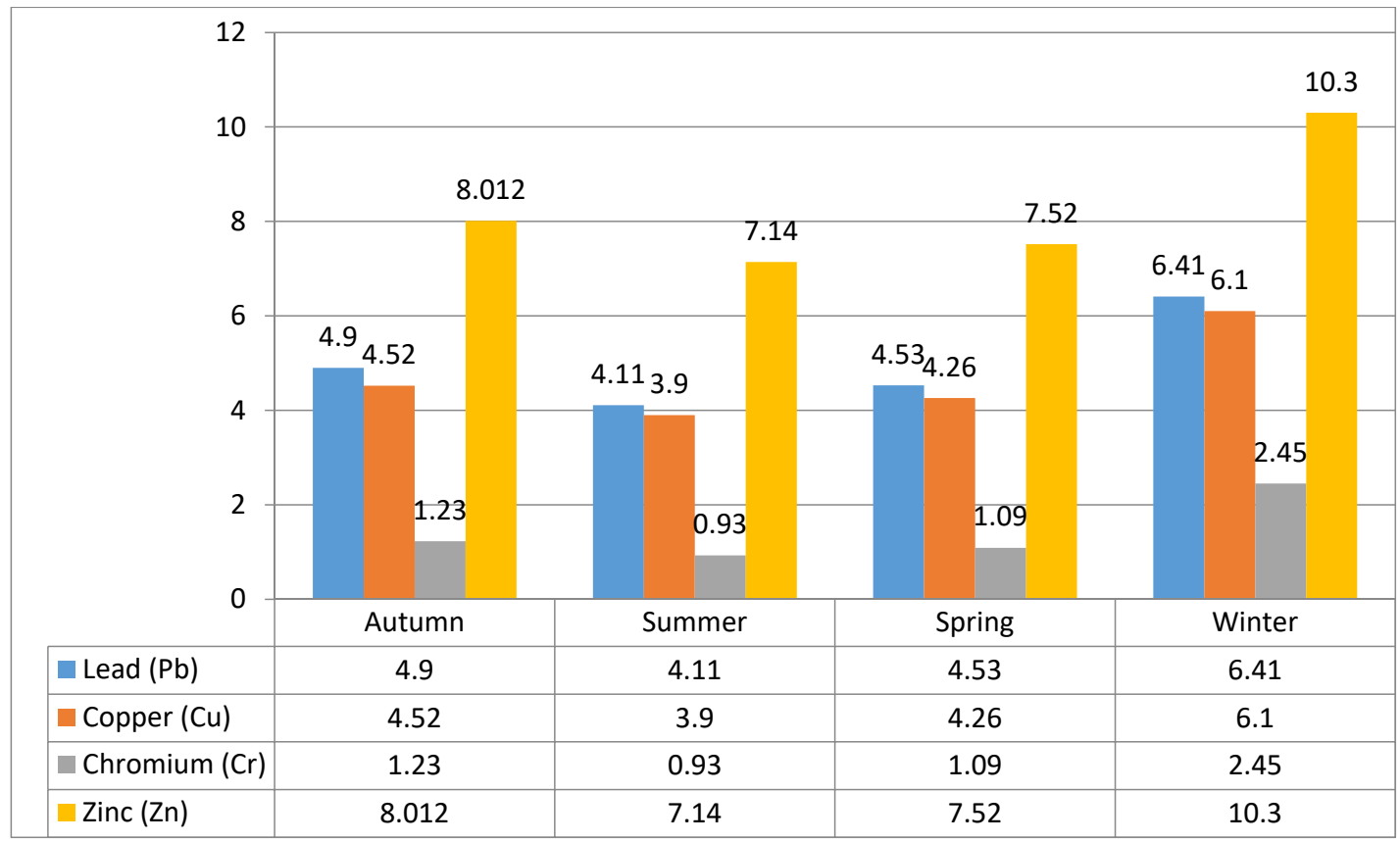

Figure 5. Laboratory measurements for the four seasons of 2017, $\mathrm{Pb}, \mathrm{Cu}, \mathrm{Cr}$, and $\mathrm{Zn}$.

Table 2. Laboratory measurements of salinity and chemicals over four seasons in 2017.

\begin{tabular}{|c|c|c|c|c|c|}
\hline \multicolumn{2}{|c|}{ Minerals $\left(\mathrm{mg} / \mathrm{dm}^{3}\right)$} & \multirow{2}{*}{$\begin{array}{c}\text { Autumn } \\
230\end{array}$} & \multirow{2}{*}{$\begin{array}{c}\text { Summer } \\
1012\end{array}$} & \multirow{2}{*}{$\begin{array}{c}\text { Spring } \\
913\end{array}$} & \multirow{2}{*}{$\begin{array}{c}\text { Winter } \\
98\end{array}$} \\
\hline \multirow{3}{*}{ Salinity } & Min & & & & \\
\hline & Max & 8975 & 17,321 & 7438 & 4109 \\
\hline & Avg & 1209 & 1069.4 & 1163.8 & 1747 \\
\hline \multirow{3}{*}{ Iron } & Min & 282 & 62 & 310 & 1101 \\
\hline & $\operatorname{Max}$ & 35,011 & 4123 & 10,951 & 2978 \\
\hline & Avg & 867.92 & 738.9 & 819.8 & 1070.4 \\
\hline \multirow{3}{*}{ Lead } & Min & 0.65 & 0.53 & 0.32 & 0.38 \\
\hline & Max & 12.3 & 8.14 & 11.87 & 21.45 \\
\hline & Avg & 4.9 & 4.11 & 4.53 & 6.41 \\
\hline \multirow{3}{*}{ Copper } & Min & 0.45 & 0.57 & 0.08 & 0.29 \\
\hline & Max & 24.65 & 16.94 & 24.62 & 38.21 \\
\hline & Avg & 4.52 & 3.9 & 4.26 & 6.1 \\
\hline \multirow{3}{*}{ Chromium } & Min & 0.04 & 0.12 & 0.022 & 0.023 \\
\hline & Max & 8.27 & 3.53 & 5.2 & 3.13 \\
\hline & Avg & 1.23 & 0.93 & 1.09 & 2.45 \\
\hline \multirow{3}{*}{ Zinc } & Min & 1.8 & 5.2 & 2.8 & 2.87 \\
\hline & Max & 2.13 & 28.65 & 41.5 & 3980 \\
\hline & Avg & 8.012 & 7.14 & 7.52 & 10.3 \\
\hline
\end{tabular}

\subsection{Mathematical Models}

The developed mathematical model can retrieve the soil quality parameters (salinity, $\mathrm{Fe}, \mathrm{Pb}, \mathrm{Cu}$, $\mathrm{Cr}$, and $\mathrm{Zn}$ ) from Landsat- 8 data. Soil quality parameter estimations are based on the integration between ground data, satellite images after processing and mathematical models. The developed model is based on the soil moisture index (SMI) and clay chemical indices (CCIs). The input of this model is based on the ground data and post-processed satellite image. These models were introduced by $[38,50]$.

The model consists of four parts: The first one depends on the B6 and B11 bands of Landsat- 8 images, which calculates the SMI; the second part is the salinity equation (SE), which depends on the output of SMI to retrieve the salinity values from Landsat- 8 images. The third part depends on the B6 and B7 bands of Landsat-8 images, which calculates the CCI. The fourth part is the chemical 
equation (CE), which depends on the output of $\mathrm{CCI}$ to retrieve the chemical values $(\mathrm{Fe}, \mathrm{Pb}, \mathrm{Cu}, \mathrm{Cr}$, and $\mathrm{Zn}$ ) from Landsat- 8 images. These four components are described below.

\subsubsection{Soil Moisture Index (SMI)}

The SMI equation was used to calculate soil moisture, depending on the relation between the B6 and B11 bands of the Landsat-8 images, as shown in Equation (1). The B6 (short wave infrared (SWIR)) band discriminates vegetation and moisture content of the soil by penetrating thin clouds with a wavelength range of 1.57-1.65 $\mu \mathrm{m}$. Meanwhile, the B11 (TIRS-2) band estimates the soil moisture and the thermal mapping in a wavelength range of $11.5-12.51 \mu \mathrm{m}[42,43,51]$.

$$
\mathrm{SMI}=\frac{(\mathrm{B} 11-\mathrm{B} 6)}{(\mathrm{B} 11+\mathrm{B} 6)}=\frac{(\mathrm{TIRS}) 2-(\mathrm{SWIR}) 1}{(\mathrm{TIRS}) 2+(\mathrm{SWIR}) 1}
$$

\subsubsection{Salinity Equation (SE)}

The SE calculates the salinity value from the Landsat- 8 images, depending on the relation between the output values of the SMI from the Landsat- 8 images and the salinity values of the ground data, as illustrated in Equations (2) and (3), and shown in Figure 6, where the $y$-axis represents the salinity values from the ground measurements while the $x$-axis represents the values of the SMI from the satellite images.

$$
\begin{gathered}
\mathrm{SE}=\mathrm{f} \times \operatorname{Exp}[\mathrm{g} \times \mathrm{SMI}]+\mathrm{i} \\
\mathrm{SE}=\mathrm{f} \times \operatorname{Exp}\left[\mathrm{g} \times \frac{(\mathrm{TIRS}) 2-(\mathrm{SWIR}) 1}{(\mathrm{TIRS}) 2+(\mathrm{SWIR}) 1}\right]+\mathrm{i}
\end{gathered}
$$

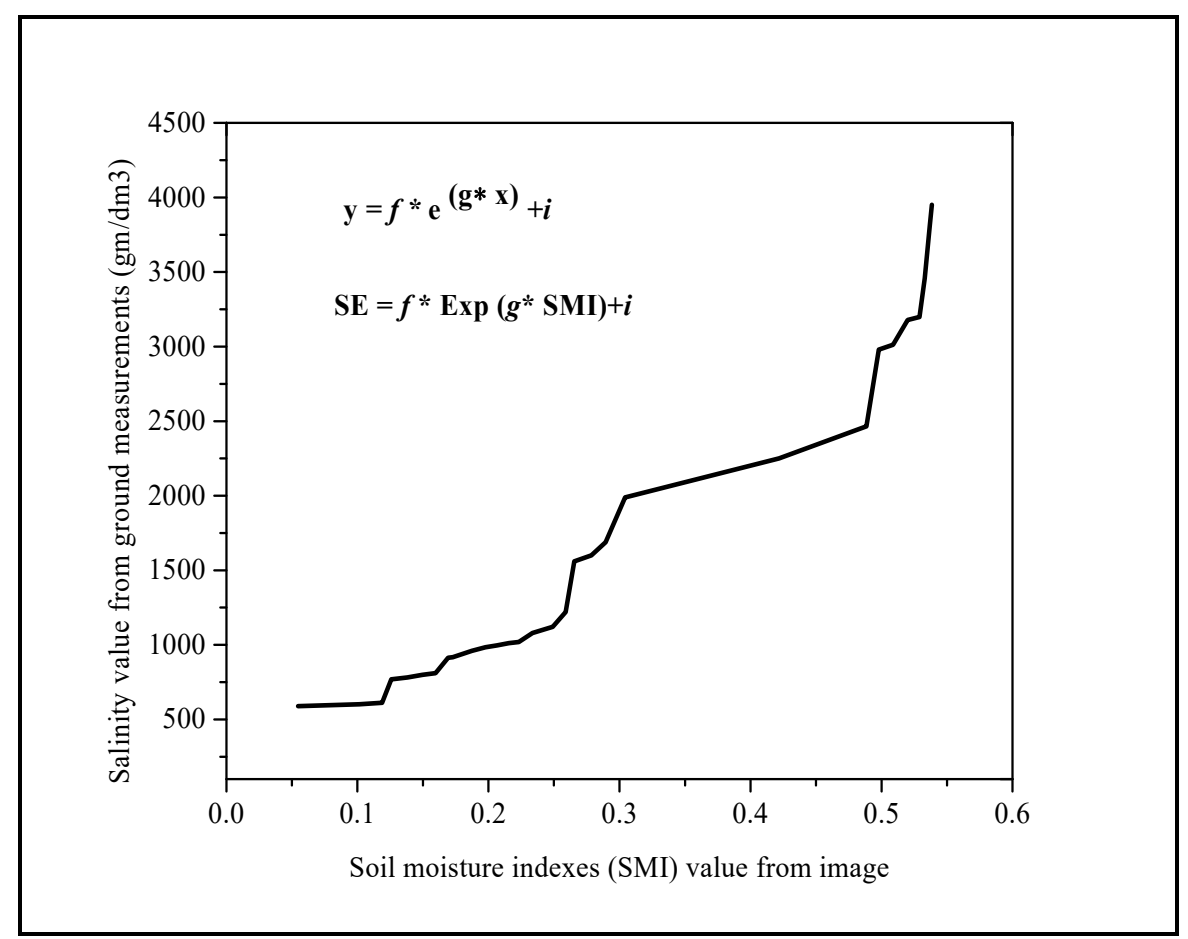

Figure 6. Salinity equation (SE) based on the relationship between soil moisture index values of the satellite images and salinity values from the ground measurements.

Here, SE represents the required values of salinity from the satellite images; SMI represents the values of the SMI from the satellite images, based on the output results of Equation (1); and f, $g$, and $i$ are constants that depend on both the values of the SMI from the satellite images and the salinity values of the ground data. The base e of the exponential function is equal to 2.718 . 


\subsubsection{Clay Chemical Indices (CCIs)}

Clay chemical indices compose all of the component chemicals-such as $\mathrm{Pb}, \mathrm{Fe}, \mathrm{Cu}, \mathrm{Cr}$, and $\mathrm{Zn}$-that are found in the clay soil of agricultural land. CCIs calculate the content of clay chemicals in the soil based on the relationship between bands B6 and B7 of the Landsat- 8 images, as shown in Equation (4). The B6 (SWIR-1) band discriminates the moisture content of soil and vegetation by penetrating thin clouds with a wavelength ranging from 1.57 to $1.65 \mu \mathrm{m}$. The B7 (SWIR-2) band improves the moisture content detection of soil and vegetation through thin cloud penetration with a wavelength ranging from 2.11 to $2.29 \mu \mathrm{m}[42,43,51]$.

$$
\mathrm{CCIs}=\frac{\mathrm{B} 6}{\mathrm{~B} 7}=\frac{(\mathrm{SWIR}) 1}{(\mathrm{SWIR}) 2}
$$

\subsubsection{Chemical Equation (CE)}

The $\mathrm{CE}$ retrieves values of chemicals $(\mathrm{Pb}, \mathrm{Fe}, \mathrm{Cu}, \mathrm{Cr}$, and $\mathrm{Zn}$ ) based on the relationship between the output results of the CCIs from the Landsat- 8 images and the ground data, as illustrated in Equations (5) and (6) and shown in Figure 7, where the $y$-axis represents the chemical values of the ground measurements and the $x$-axis represents the CCIs values from the satellite images.

$$
\begin{gathered}
\mathrm{CE}=\mathrm{p} \times(\mathrm{CCIs})^{\mathrm{n}}+\mathrm{h} \\
\mathrm{CE}=\mathrm{p} \times\left(\frac{(\mathrm{SWIR}) 1}{(\mathrm{SWIR}) 2}\right)^{\mathrm{n}}+\mathrm{h}
\end{gathered}
$$

where $\mathrm{CE}$ represents the concentration values of the chemicals $(\mathrm{Pb}, \mathrm{Fe}, \mathrm{Cu}, \mathrm{Cr}$, and $\mathrm{Zn})$ acquired from the satellite images; CCIs represents the clay chemical indices from the satellite images based on the output results of Equation (4); $\mathrm{p}$ and $\mathrm{h}$ are constants that depend on the chemical values of the ground data and the indices of the clay chemicals from the satellite images, respectively; and the power $\mathrm{n}$ is an integer. All of the previous steps of the model must be repeated for each season of study.

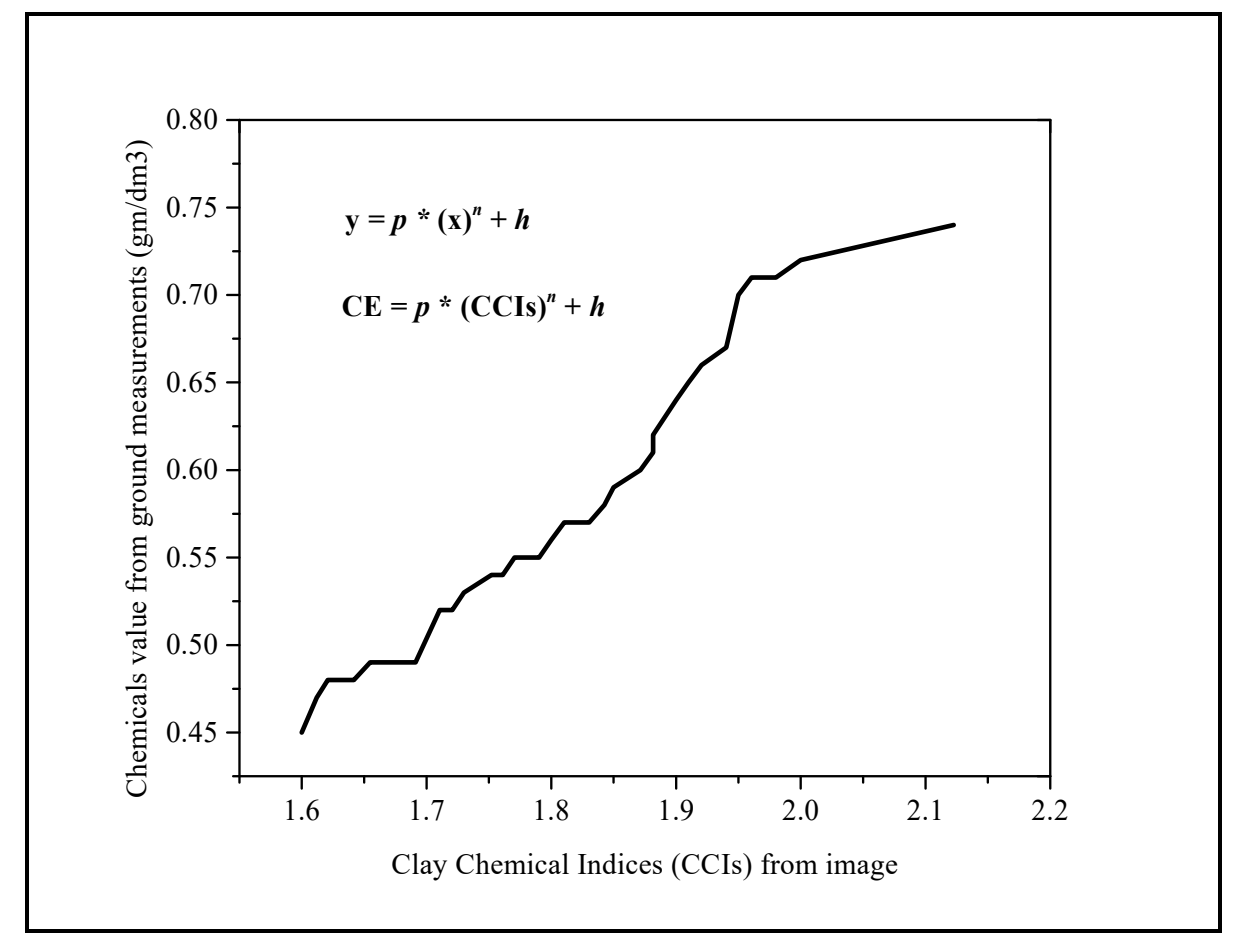

Figure 7. Chemical equation (CE) based on the relationship between the clay chemicals indices from the satellite imagery, and the chemical values of the ground measurements. 


\subsection{Image Classification}

Several image classification techniques can be used to classify the satellite images, such as maximum likelihood (ML), minimum distance (MD), artificial neural network (ANN), support vector machine (SVM), and decision tree (DT) [4,24]. The present study classified soil quality parameters using images of agricultural land in Al-Hawizeh marsh during four seasons of 2017 depending on the output results of SE and CE equations. DT classification was used in this study. It is an advanced approach for image classification, which depends on the layered or stratified approach to solve the problems of distinguishing between spectral classes [4,24]. DT uses data from many sources to make a single decision tree classifier. This performs multistage classification using a series of binary decisions to place pixels into classes. Input data can be obtained from various sources and data types. The results of the decisions are classes that can be saved as trees to apply them for other datasets [52]. This classification refers to all parameters simultaneously in one stage. The output of DT classification results can display all soil quality parameters in one image. Thus, DT in this case is considered as the optimal approach. This approach was repeated for each season in this study.

\subsection{Data Visualization}

The output results are presented as DT classifications for both SE and CE equations after performing validation. The output of the DT results are presented as one image for salinity, $\mathrm{Fe}, \mathrm{Pb}, \mathrm{Cu}, \mathrm{Cr}$, and $\mathrm{Zn}$. This procedure was performed for each season.

\section{Results and Discussion}

The mathematical models were combined with the Landsat- 8 satellite images and synchronized with the ground data to retrieve soil quality parameters for agricultural land at Al-Hawizeh marsh. The values of soil quality parameters (salinity, $\mathrm{Fe}, \mathrm{Pb}, \mathrm{Cu}, \mathrm{Cr}$, and $\mathrm{Zn}$ ) are evaluated from Landsat- 8 data based on the mathematical models. These values indicate the status of soil quality for agricultural lands of Al-Hawizeh marsh from the satellite images during four seasons of 2017. Table 3 summarizes the evaluated soil quality parameters.

Table 3. Evaluated soil quality parameters values from images during four seasons of 2017.

\begin{tabular}{|c|c|c|c|c|c|}
\hline \multicolumn{2}{|c|}{ Minerals $\left(\mathrm{mg} / \mathrm{dm}^{3}\right)$} & \multirow{2}{*}{$\begin{array}{c}\text { Autumn } \\
196\end{array}$} & \multirow{2}{*}{$\begin{array}{c}\text { Summer } \\
992\end{array}$} & \multirow{2}{*}{$\begin{array}{c}\text { Spring } \\
813\end{array}$} & \multirow{2}{*}{$\begin{array}{c}\text { Winter } \\
83\end{array}$} \\
\hline \multirow{3}{*}{ Salinity } & Min & & & & \\
\hline & Max & 9235 & 18,214 & 7944 & 4628 \\
\hline & Avg & 1175 & 1010 & 1105 & 1789 \\
\hline \multirow{4}{*}{ Iron } & Min & 274 & 56 & 290 & 1013 \\
\hline & Max & 35,531 & 4604 & 11,234 & 3818 \\
\hline & Avg & 813 & 784 & 842 & 1106 \\
\hline & Min & 0.47 & 0.47 & 0.37 & 0.29 \\
\hline \multirow[t]{2}{*}{ Lead } & Max & 14 & 9 & 13 & 25 \\
\hline & Avg & 4.85 & 3.79 & 4.74 & 7.2 \\
\hline \multirow{3}{*}{ Copper } & Min & 0.42 & 0.5 & 0.05 & 0.26 \\
\hline & Max & 26 & 18.4 & 26 & 40 \\
\hline & Avg & 3.9 & 3.1 & 4.45 & 7.5 \\
\hline \multirow{3}{*}{ Chromium } & Min & 0.03 & 0.08 & 0.015 & 0.017 \\
\hline & Max & 10.7 & 4.3 & 5.9 & 3.73 \\
\hline & Avg & 1.28 & 0.73 & 1.03 & 2.91 \\
\hline \multirow{3}{*}{ Zinc } & Min & 1.6 & 4.9 & 2.7 & 2.74 \\
\hline & Max & 2.95 & 32 & 46 & 4028 \\
\hline & Avg & 8.25 & 6 & 7.05 & 12 \\
\hline
\end{tabular}




\subsection{Salinity Values}

Figure 8 shows the seasonal variation of soil salinity obtained using the SMI model, which is observed to be lowest during summer and highest during winter. The average salinity concentrations during autumn, summer, spring, and winter are 1175, 1010, 1105, and $1789 \mathrm{mg} / \mathrm{dm}^{3}$, respectively, determined by the soil moisture index. This indicated a reduction of SMI in the summer and rise in the winter. The SMI values are decided by the spectral signatures of Landsat- 8 Short Wave Infrared (SWIR-1) band B6 and Thermal Infrared Sensor (TIRS-2) band B11. These images (bands) are considered as suitable and sensitive as far as the soil moisture indexes are concerned. Salinity concentrations displayed a positive relationship with the SMI values $[18,42,43,51]$.

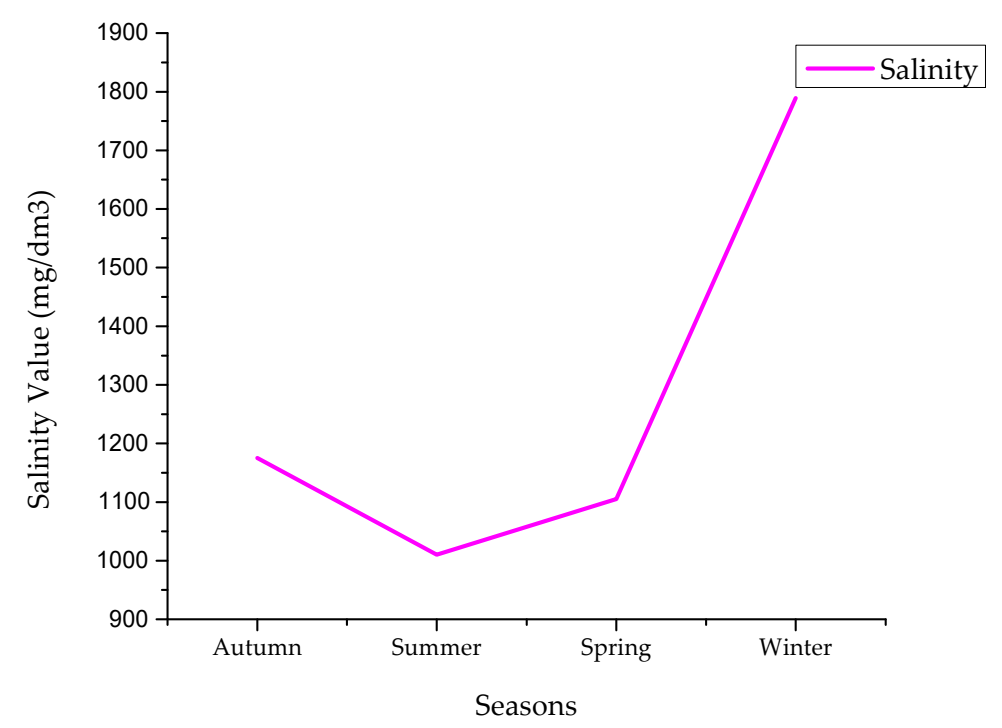

Figure 8. Concentration values for salinity from images during four seasons of 2017.

\subsection{Iron Values}

Figure 9 shows the seasonal variation of iron content obtained using the CCIs model, which is observed to be lowest during summer and highest during winter. The average Fe concentrations during autumn, summer, spring, and winter are $813,784,842$, and $1106 \mathrm{mg} / \mathrm{dm}^{3}$, respectively, which was determined by the clay chemical indices. This indicated a reduction of the clay chemicals in the summer and a rise during winter. The CCIs values are decided by the spectral signatures of Landsat-8 Short Wave Infrared (SWIR-1) band B6 having and Short Wave Infrared (SWIR-2) band B7 with wavelength range 2.11-2.29 $\mu \mathrm{m}$. These images (bands) are considered as suitable and sensitive as far as the CCIs are concerned. Fe concentrations displayed a positive relationship among the clay chemicals indices values $[18,42,43,51]$. 


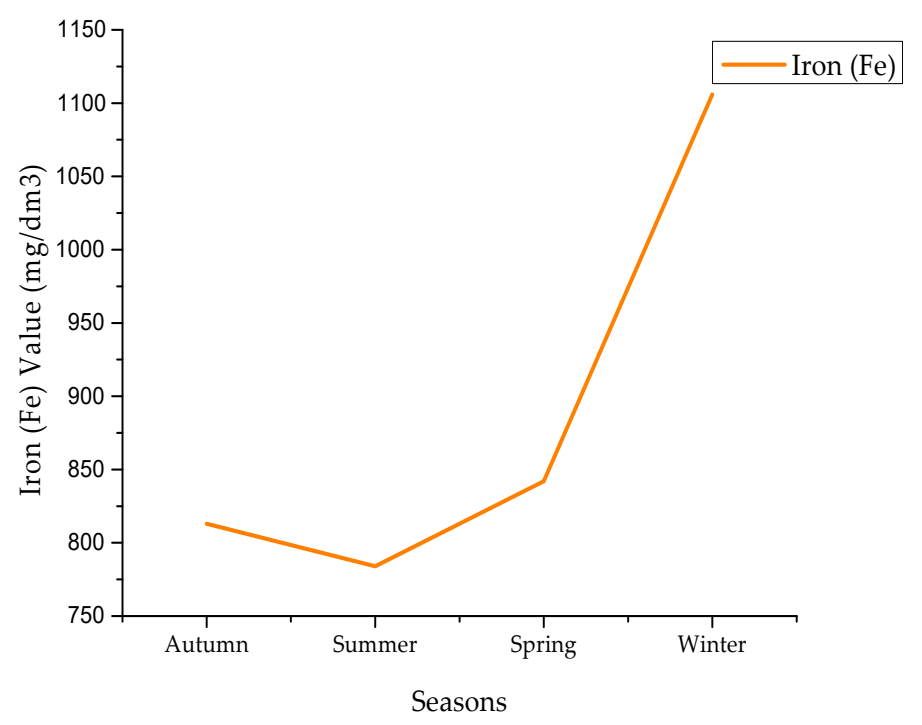

Figure 9. Concentration values for (Fe) from images during four seasons of 2017.

\subsection{Lead Values}

The $\mathrm{Pb}$ concentrations that were evaluated using CCIs model during the four seasons were lowest in summer and highest in winter (Figure 10). The average $\mathrm{Pb}$ concentrations during autumn, summer, spring, and winter were $4.85,3.79,4.74$, and $7.2 \mathrm{mg} / \mathrm{dm}^{3}$, respectively, determined by CCIs. This indicated a reduction the indices of the clay chemicals in the summer and a rise during winter. $\mathrm{Pb}$ concentrations displayed a positive relationship with the CCIs values $[18,42,43,51]$.

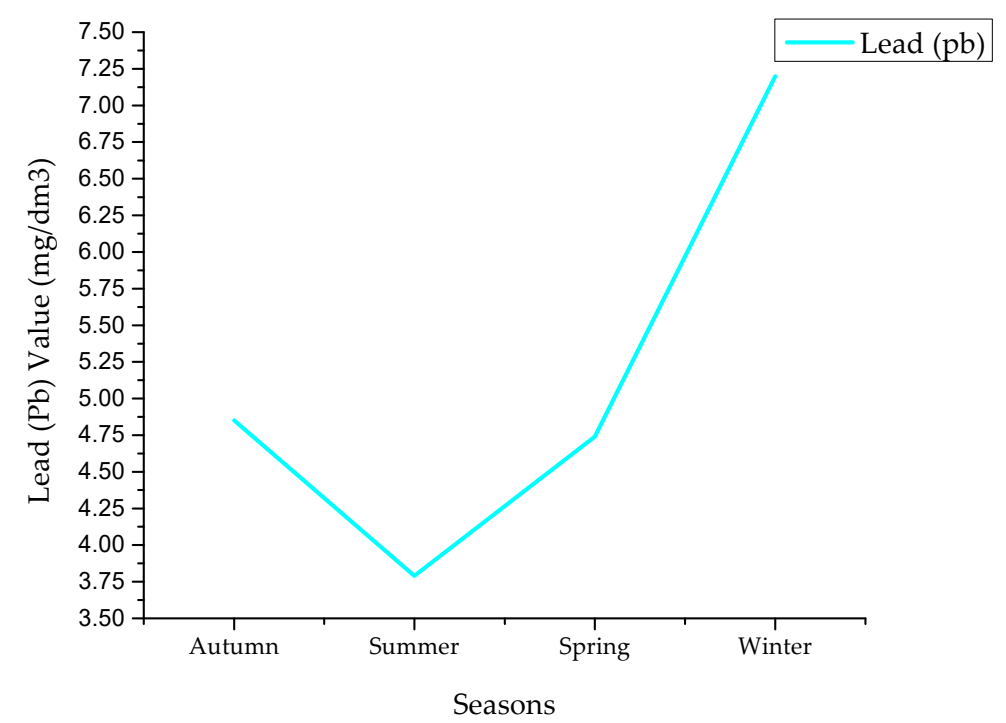

Figure 10. Concentration values for $(\mathrm{Pb})$ from image during four seasons in 2017.

\subsection{Copper Values}

Figure 11 shows the seasonal variation of $\mathrm{Cu}$ content obtained using the CCIs model, which was observed to be lowest during summer and highest during winter. The average $\mathrm{Cu}$ concentrations during autumn, summer, spring and winter were $3.9,3.1,4.45$, and $7.5 \mathrm{mg} / \mathrm{dm}^{3}$, respectively, which was determined by the CCIs. This indicated a reduction in the CCIs in the summer and a rise in the winter. $\mathrm{Cu}$ concentrations displayed a positive relationship with CCIs values [18,42,43,51]. 


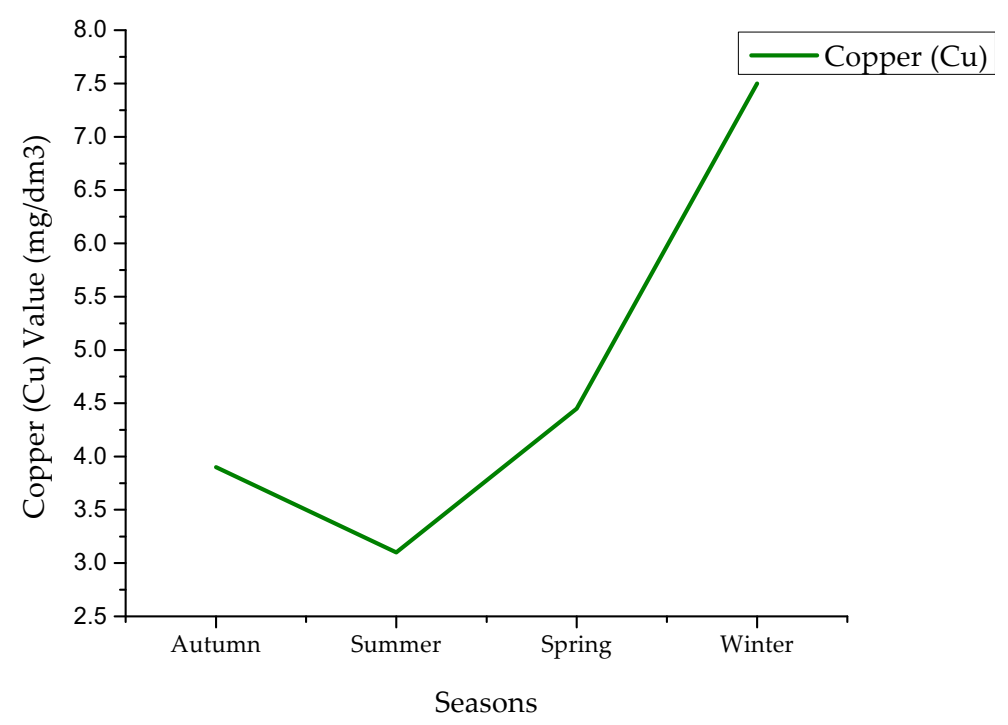

Figure 11. Concentration values for $(\mathrm{Cu})$ from image during four seasons.

\subsection{Chromium Values}

The $\mathrm{Cr}$ concentrations were evaluated using CCIs and were lowest during summer and highest during winter (Figure 12). The average $\mathrm{Cr}$ concentrations during autumn, summer, spring, and winter were $1.28,0.73,1.03$, and $2.91 \mathrm{mg} / \mathrm{dm}^{3}$, respectively, determined by CCIs. This indicated a reduction of CCIs in the summer and a rise in the winter. $\mathrm{Cr}$ concentrations displayed a positive relationship with the clay chemical index values $[18,42,43,51]$.

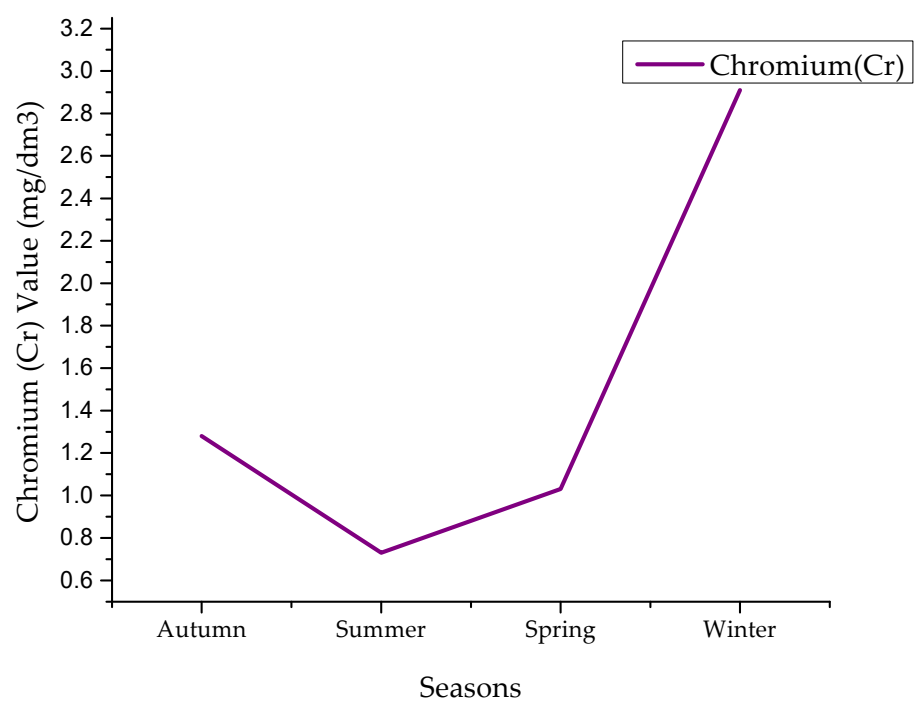

Figure 12. Concentration values for $(\mathrm{Cr})$ from image during four seasons.

\subsection{Zinc Values}

Figure 13 demonstrates the seasonal variation of $\mathrm{Zn}$ contents obtained using CCIs model, which was observed to be lowest during summer and highest during winter. The average $\mathrm{Zn}$ concentrations during autumn, summer, spring, and winter were $8.25,6,7.05$, and $12 \mathrm{mg} / \mathrm{dm}^{3}$, respectively, which is decided by the clay chemical indices. This indicated a reduction of CCIs in the summer and a rise in the winter. Zn concentrations displayed a positive relationship with CCIs values [18,42,43,51]. 


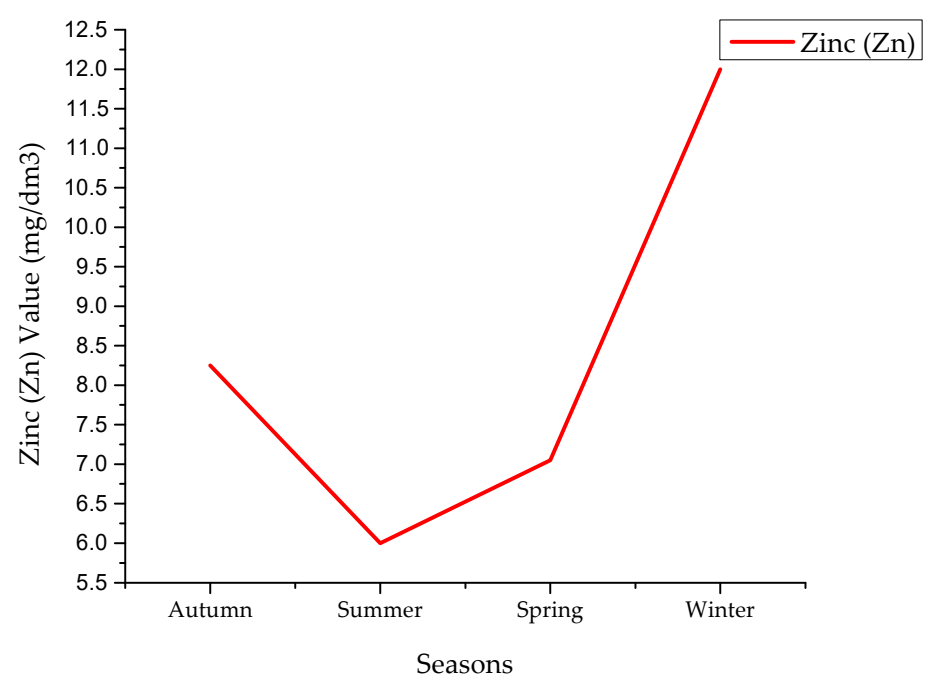

Figure 13. Concentration values for $(\mathrm{Zn})$ from image during four seasons.

From the previous results, we found that all values of salinity and chemical parameters decreased in the summer and increased in the winter based on the SMI and CCIs values in the soil of the agricultural land. The values of SMI and CCIs are dependent on the amount of water flowing from Al-Hawizeh marsh. This indicated a reduction in flow of water amounts during the summer and a rise in the winter. The high temperatures and subsequent drying of soil in the summer led to a further decrease in the SMI and CCIs values in the summer. All of these results exceeded the maximum allowable concentration of salinity and chemicals in agricultural land based on Iraq's standards of soil for agriculture (Law No. 25/1967, environmental protection and public agricultural lands soil from pollution) [18].

\section{Image Classifications}

Figure 14 presents the minimum and the maximum spatial distribution of salinity and chemical $(\mathrm{Fe}, \mathrm{Pb}, \mathrm{Cu}, \mathrm{Cr}$, and $\mathrm{Zn}$ ) contents for soils in the agricultural lands of Al-Hawizah marsh obtained using the mathematical models during all four seasons. Figure 14A represents the spatial distribution with the minimum and maximum concentration values for salinity, $\mathrm{Fe}, \mathrm{Pb}, \mathrm{Cu}, \mathrm{Cr}$, and $\mathrm{Zn}$ in the autumn, which were determined to be (196-9235), (274-35,531), (0.47-14), (0.42-26), (0.03-10.7), and (1.6-2.95) $\mathrm{mg} / \mathrm{dm}^{3}$, respectively. Figure $14 \mathrm{~B}$ represents the spatial distribution with the minimum and maximum concentration values for salinity, $\mathrm{Fe}, \mathrm{Pb}, \mathrm{Cu}, \mathrm{Cr}$, and $\mathrm{Zn}$ in the summer, which were (992-18,214), (56-4604), (0.47-9), (0.5-18.4), (0.08-4.3), and (4.9-32) $\mathrm{mg} / \mathrm{dm}^{3}$, respectively. Figure $14 \mathrm{C}$ represents the spatial distribution of the minimum and maximum concentration of salinity, $\mathrm{Fe}, \mathrm{Pb}, \mathrm{Cu}, \mathrm{Cr}$, and $\mathrm{Zn}$ in the spring, which were (813-7944), (290-11234), (0.37-13), (0.05-26), (0.015-5.9), and (2.7-4.6) $\mathrm{gm} / \mathrm{dm}^{3}$, respectively. Figure $14 \mathrm{D}$ represents the spatial distribution of the minimum and maximum salinity, $\mathrm{Fe}, \mathrm{Pb}, \mathrm{Cu}, \mathrm{Cr}$, and $\mathrm{Zn}$ in the winter, which were (83-4628), (1013-3818), (0.29-25), (0.26-40), (0.017-3.73), and (2.74-4028) $\mathrm{mg} / \mathrm{dm}^{3}$, respectively. Figure 15 illustrates two-dimensional image layers for salinity and chemicals distribution during all four seasons based on the proposed models.

The salinity values were observed to be lowest during the summer and highest during the winter, which were decided by the SMI, indicating a reduction of the soil moisture indexes during summer and a rise in the winter. The soil moisture index values were decided by the spectral signatures of the Landsat-8 Short Wave Infrared (SWIR-1) band B6 and the Thermal Infrared Sensor (TIRS-2) band B11, which are considered suitable and sensitive as far as SMI is concerned. These salinity concentrations displayed a positive relationship among the soil moisture index values. [42,43,51].

All chemical values were determined using the CCIs and indicated a reduction of the clay CCIs in the summer and a rise during winter. The CCIs were determined by the spectral signatures of the Landsat-8 SWIR-1 band B6 and SWIR-2 band B7, which are considered suitable and sensitive for this purpose. The chemical concentrations displayed a positive relationship with CCI values [19]. 

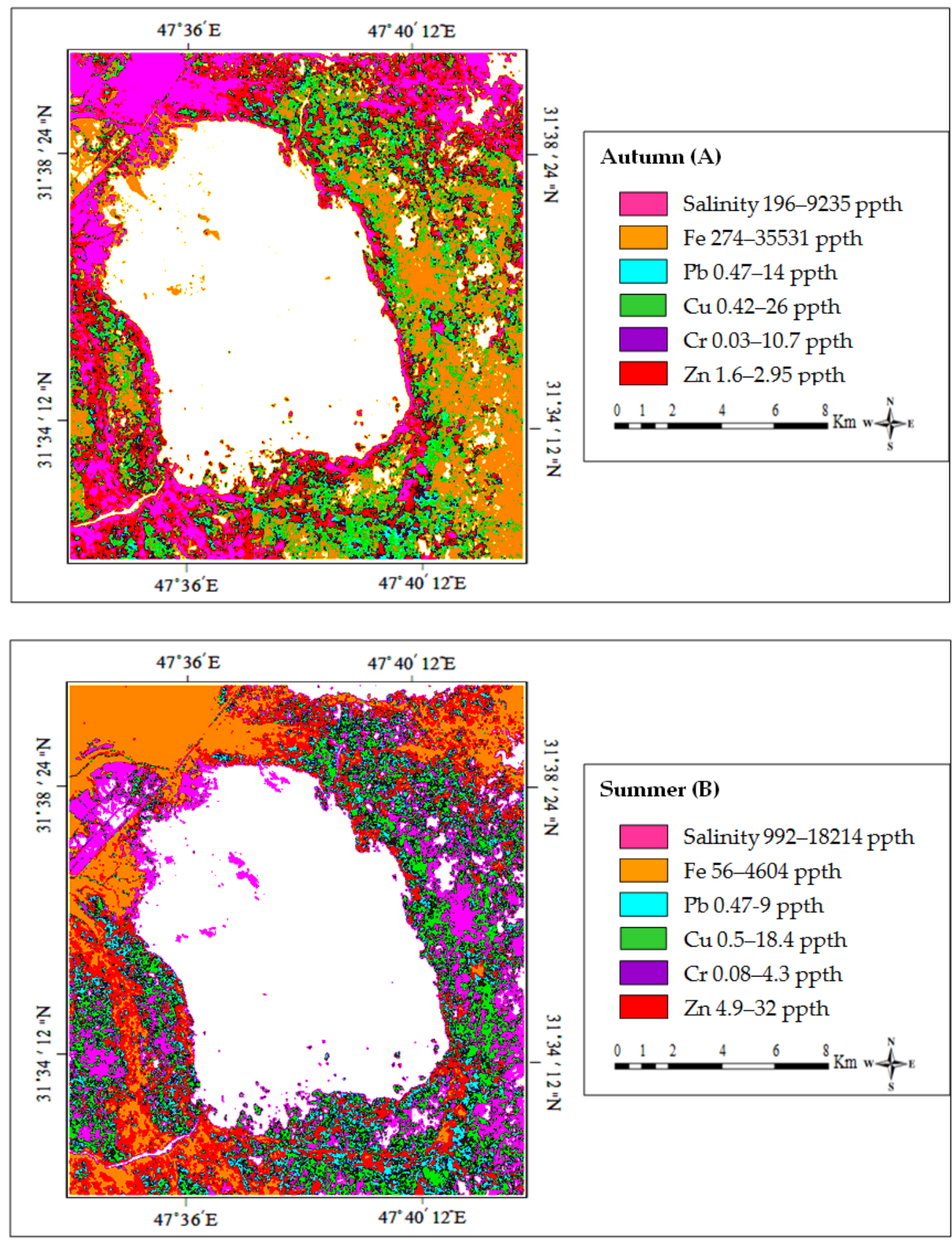

Figure 14. Cont. 

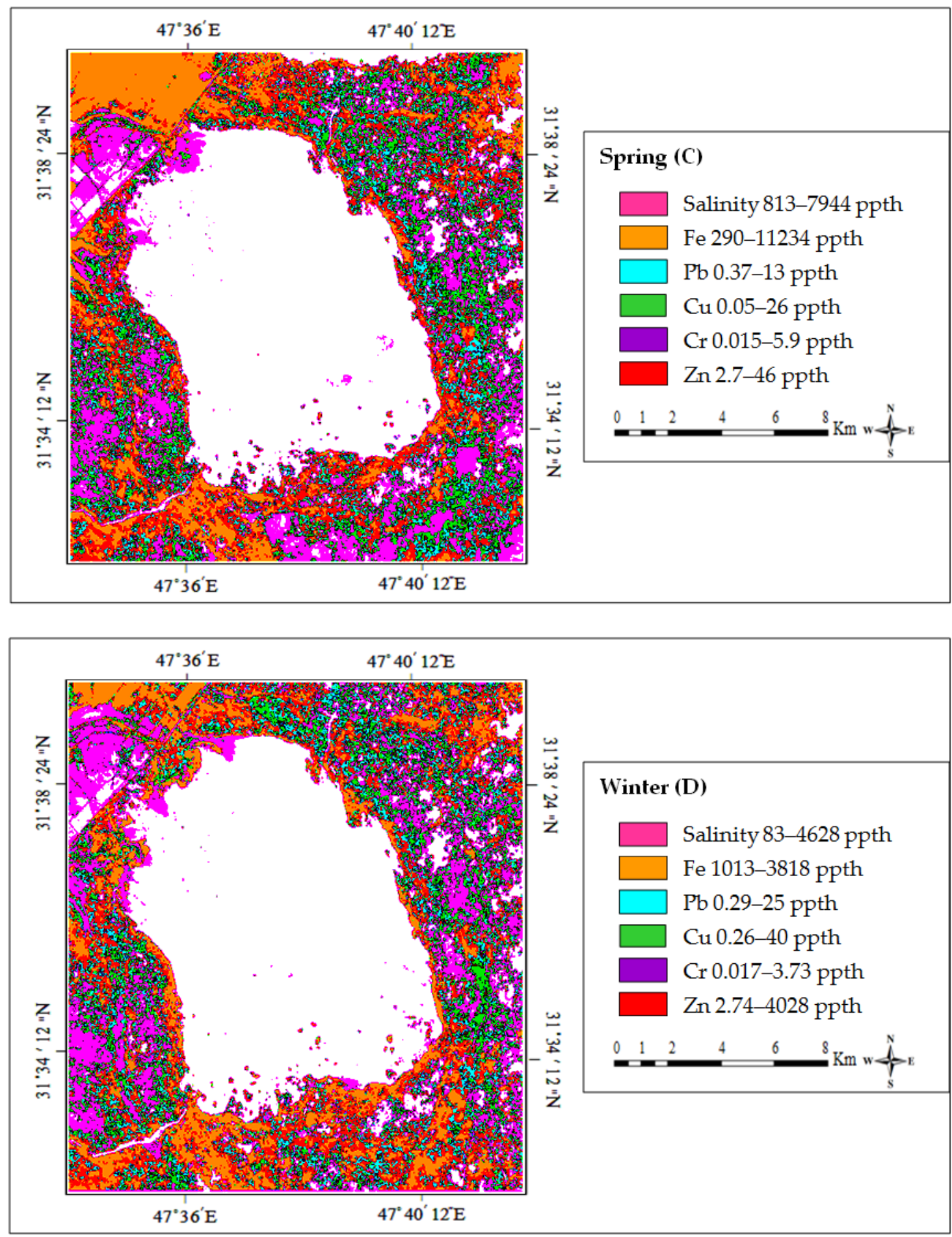

Figure 14. Salinity and chemical spatial distributions of the agricultural lands based on the proposed models during all four seasons: (A) autumn, (B) summer, (C) spring, and (D) winter. 


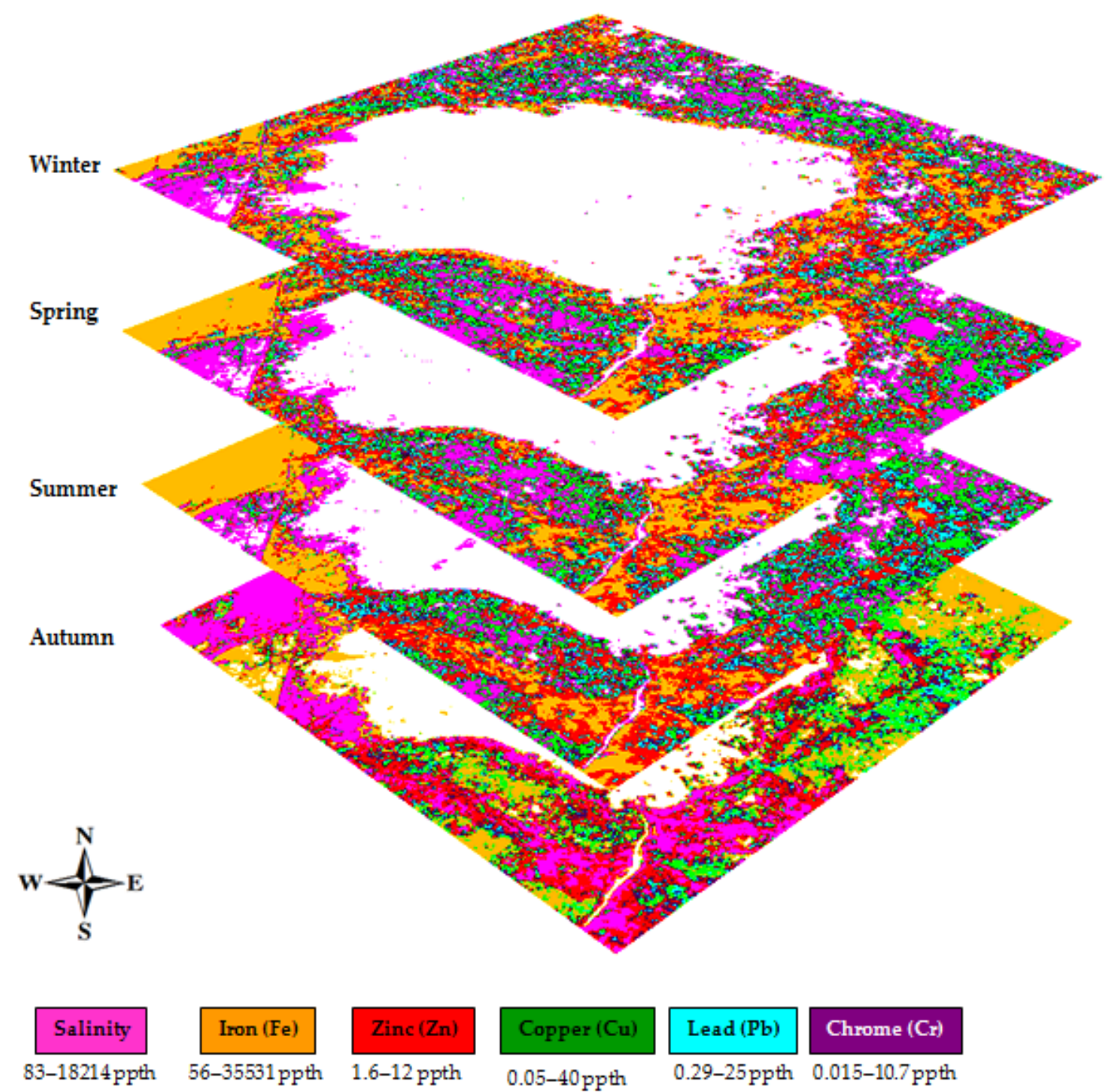

Figure 15. Two-dimensional image layers for salinity and chemical distribution during all four seasons based on the proposed models.

\section{Conclusions}

The agricultural land surrounding Al-Hawizeh marsh in southern Iraq is considered a habitat provider for biodiversity and an enriched resource for the production of several crops. The neglect and wars of recent years are factors that may have led to an increase of salinity, iron, lead, copper, chromium, and zinc in the soil. Techniques have been developed for the detection and monitoring of physical and chemical parameters in soils.

AAS is a technique that can be used to measure the salinity and chemicals in soils. The mathematical models of this study were based on the B6, B7, and B11 bands of Lasndsat-8 satellite imagery. These bands were suitable to combine with the mathematical models for assessing and monitoring the spatial distribution of salinity and chemicals from satellite imagery. It is concluded that the integration of mathematical models with remote sensing data and GIS can provide a powerful tool for predicting, assessing, monitoring, managing, and mapping salinity and chemicals components.

The seasonal variation of average salinity and chemicals was obtained using the SE and CE equations. The salinity values were evaluated by using the SE during all four seasons. The average salinity concentrations during autumn, summer, spring, and winter were 1175, 1010, 1105, and 1789 $\mathrm{mg} / \mathrm{dm}^{3}$, respectively. These values were determined by the SMI. This indicated a reduction of the SMI 
values in the summer and a rise in the winter. These salinity concentrations displayed a positive relationship with SMI values.

The chemical concentrations were obtained using the CE equation. These values were observed to be lowest during the summer and highest during the winter. The average values for (Fe) during the autumn, summer, spring, and winter were $813,784,842$, and $1106 \mathrm{mg} / \mathrm{dm}^{3}$, respectively. The average values for $(\mathrm{Pb})$ during the autumn, summer, spring, and winter were $4.85,3.79,4.74$, and $7.2 \mathrm{mg} / \mathrm{dm}^{3}$, respectively. The average values for $(\mathrm{Cu})$ during the autumn, summer, spring and winter were found to be $3.9,3.1,4.45$, and $7.5 \mathrm{mg} / \mathrm{dm}^{3}$, respectively. The average values for (Cr) during the autumn, summer, spring, and winter were found to be $1.28,0.73,1.03$, and $2.91 \mathrm{mg} / \mathrm{dm}^{3}$, respectively. The average values for ( $\mathrm{Zn}$ ) during the autumn, summer, spring, and winter were found to be $8.25,6,7.05$, and $12 \mathrm{mg} / \mathrm{dm}^{3}$, respectively. These values were determined using the CCIs in the soil. This indicated a reduction of the CCIs in the summer and a rise in the winter season. These chemicals concentrations displayed a positive relationship with values of the CCIs.

To conclude on the salinity and chemical values obtained based on the SMI and CCIs results, the SMI and CCIs were dependent on the amount of water coming from Al-Hawizeh marsh during the four seasons. This indicated a reduction in water during summer and an increase in winter. This was exacerbated by the high temperatures and dry soil in the summer. The salinity and chemical concentrations were above the maximum allowable concentration in agricultural land based on Iraq's standards for agricultural land pollution.

The DT classification scheme provided good results for this study. The DT classification depended on the output results of salinity and chemicals for both the SE and CE equations. This classification refers to all the parameters simultaneously in one stage. The output of the DT classification can display all the soil quality parameters (salinity, $\mathrm{Fe}, \mathrm{Pb}, \mathrm{Cu}, \mathrm{Cr}$, and $\mathrm{Zn}$ ) in one image. This approach was repeated for each season. In conclusion, the developed systematic and generic approach may constitute a basis for determining the soil quality parameters in agricultural land worldwide.

Author Contributions: Conceptualization, H.A.H., H.D., A.S.D., W.H.H., and H.M.H.; Methodology, H.A.H., H.D., W.H.H., A.S.D., and H.M.H.; Validation, H.A.H., H.D., A.S.D., N.A.-A., W.H.H., and H.M.H.; Formal analysis, H.A.H., H.D., W.H.H., A.S.D., and H.M.H.; Investigation, H.A.H., H.D., W.H.H., A.S.D., and H.M.H.; Data corruption, A.H.H., H.D., W.H.H., A.S.D., and H.M.H.; Writing-original draft preparation, all authors; Writing-review and editing, all authors; Visualization, N.A.-A.; Project administration, N.A.-A. All authors read and agreed to the published version of the manuscript.

Funding: This research received no external funding.

Conflicts of Interest: The authors declare no conflict of interest.

\section{References}

1. Al-Handal, A.; Hu, C. MODIS observations of human-induced changes in the Mesopotamian Marshes in Iraq. Wetlands 2015, 35, 31-40. [CrossRef]

2. Azab, A.M. Integrating GIS, remote sensing; mathematical modelling for surface water quality management in irrigated watersheds. Ihe Delft Inst. Water Educ. 2012, 24, 75.

3. Kerekes, J.P.; Baum, J.E. Full-spectrum spectral imaging system analytical model, Geoscience; Remote Sensing. IEEE Trans. 2005, 43, 571-580.

4. Mather, P.M.; Koch, M. Remote Sensing: Basic Principles: Computer Processing of Remotely-Sensed Images: An Introduction; John Wiley \& Sons: Hoboken, NJ, USA, 2011; p. 67.

5. Ongley, E.D. Water quality management: Design, financing; sustainability considerations-II. In Proceedings of the 2000 Invited Presentation at the World Bank's Water Week Conference: Towards a Strategy for Managing Water Quality Management, Washington, DC, USA, 2-4 April 2000; Volume 4, p. 34.

6. Ustin, S. Manual of Remote Sensing: Remote Sensing for Natural Resource management; Environmental Monitoring; John Wiley \& Sons: Hoboken, NJ, USA, 2004; Volume 6, pp. 23-56.

7. Zacharias, I.; Gianni, A. Hydrodynamic; Dispersion Modeling as a Tool for Restoration of Coastal Ecosystems, Application to a Re-Flooded Lagoon. Environ. Model. Softw. 2008, 23, 751-767. [CrossRef] 
8. Bahrawi, J.A. Evaluation of distinctive normalized difference vegetation indices in soil erosion estimation using remote sensing concepts in WadiYalamlam, Saudi Arabia. Indian J. Geo Mar. Sci. 2018, 47, 2087-2093.

9. Lu, D.; Mausel, P.; Brondizio, E.; Moran, E. Change detection techniques. Int. J. Remote Sens. 2004, 25, 236-240. [CrossRef]

10. Azab, A. Integrating GIS, Remote Sensing; Mathematical moDelling for Surface Water Quality Management in Irrigated Watersheds; IHE Delft Institute for Water Education: Delft, The Netherlands, 2012; p. 21.

11. Mujumdar, N. World development report, 2000/2001: Attacking poverty. Indian J. Agric. Econ. 2011, 56, 146.

12. Green, E.A. Hydropolitics in the Middle East; US Policy; DTIC Document: Fort Belvoir, VA, USA, 1993; Volume 3, p. 87.

13. Lowi, M.R. Rivers of conflict, rivers of peace. J. Int. Aff. 1995, 49, 123-144.

14. Maltby, E. An Environmental \& Ecological Study of the Marshlands of Mesopotamia, Draft Consultative Bulletin: AMAR appeal Trust; University of Exeter, Wetland Ecosystems Research Group: London, UK, 1994; Volume 3, pp. 19-23.

15. Nicholson, E.; Clark, P. Iraqi Marshlands: Politico's Pub; AMAR International Charitable Foundation: London, UK, 2003; Volume 2, p. 45.

16. Partow, H. The Mesopotamian Marshlands: Demise of an Ecosystem. Nairobi (Kenya): Division of Early Warning; Assessment, United Nations Environment Programme; UNEP publication UNEP/DEWA: Nairobi, Kenya, 2001; Volume 4, pp. 1-3.

17. Hayder, D.; Shattri, M.; Noordin, A.; Biswajeet, P. Band-to-band registration model for near-equatorial Earth observation satellite images with the use of automatic control point extraction. Int. J. Remote Sens. 2015, 36, 2184-2200.

18. Hasab, H.A.; Jawad, H.A.; Dibs, H.; Hussain, H.M.; Al-Ansari, N. Evaluation of Water Quality Parameters in Marshes Zone Southern of Iraq Based on Remote Sensing; GIS Techniques. Water, AirSoil Pollut. 2020, 231, 1-11. [CrossRef]

19. Schwarte, C. Environmental Protection in islamic Law: An Overview on Potential Influences for Legal Developments in Iraq. Local Environ. 2003, 8, 567-576. [CrossRef]

20. Hashim, A.; Marghany, M. Developing a hydrological model for water quality in Iraq marshes zone using Landsat-TM. J. IopscienceEarth; Environ. Sci. 2016, 37, 012073. [CrossRef]

21. Ammenberg, P.; Flink, P.; Lindell, T.; Pierson, D.; Strombeck, N. Bio-optical modelling combined with remote sensing to assess water quality. Int. J. Remote Sens. 2002, 23, 1621-1638. [CrossRef]

22. Goodchild, M.F.; Steyaert, L.T.; Parks, B.O. GIS; Environmental Modeling: Progress; Research Issues; John Wiley \& Sons: Hoboken, NJ, USA, 1996; Volume 25, p. 183.

23. Dellapenna, J.W.; Nicholason, E.; Clark, P. The Iraqi Marshlands; A Human Environmental Study; AMAR International Charitable Foundation: London, UK, 2001; Volume 7, p. 123.

24. Mather, P.M.; Koch, M. Computer Processing of Remotely-Sensed Images: An Introduction; John Wiley \& Sons: Hoboken, NJ, USA, 2011; p. 95.

25. El-Din, M.S.; Gaber, A.; Koch, M.; Ahmed, R.S.; Bahgat, I. Remote Sensing Application for Water Quality Assessment in Lake T imsah, Suez Canal, Egypt. J. Remote Sens. Technol. 2013, 1, 61. [CrossRef]

26. Guerrero, D.V.C.; NO, U.G.A. The Anacostia River: Ecological Studies of Water Pollution Biology; DC Water Resources Research Center: Washington, DC, USA, 1991.

27. Liu, H.; Zheng, L.; Yin, S. Multi-perspective analysis of vegetation cover changes; driving factors of long time series based on climate; terrain data in Hanjiang River Basin, China. Arab. J. Geosci. 2018, 11, 509. [CrossRef]

28. Cao, X.; Feng, Y.; Wang, J. Remote sensing monitoring the spatio-temporal changes of aridification in the Mongolian Plateau based on the general Ts-NDVI space, 1981-2012. J. Earth Syst. Sci. 2017, 126, 58. [CrossRef]

29. Jensen, J.R. Introduction to Digital Image Processing: A Remote Sensing Perspective, 3rd ed.; Prentice Hall: Upper Saddle River, NJ, USA, 2005; pp. 239-247.

30. Zhuo, L.; Han, D.; Dai, Q. Exploration of empirical relationship between surface soil temperature; surface soil moisture over two catchments of contrasting climates; land covers. Arab. J. Geosci. 2017, 10, 410. [CrossRef]

31. Roy, A.; Keesari, T.; Sinha, U.K.; Sabarathinam, C. Delineating groundwater prospect zones in a region with extreme climatic conditions using GIS; remote sensing techniques: A case study from central India. J. Earth Syst. Sci. 2019, 128, 201. [CrossRef] 
32. Dehmordi, L.M.; Savari, A.; Dostshenas, A.; Asgari, H.M.; Abasi, A. Remote chlorophyll-a, SST; kd490 retrieval in Northwest Persian gulf using landsat 8 satellite data. Indian J. Geo Mar. Sci. 2018, 47, 148-169.

33. Jacintha, T.; Rajasree, S.R.; Kumar, J.D.; Sriganesh, J. Assessment of wetland change dynamics of Chennai coast, Tamil Nadu, India, using satellite remote sensing. Indian J. Geo Mar. Sci. 2019, 48, 1258-1266.

34. Giri, S.; Singh, A.K.; Mahato, M.K. Metal contamination of agricultural soils in the copper mining areas of Singhbhum shear zone in India. J. Earth Syst. Sci. 2017, 126, 49. [CrossRef]

35. Ennaji, W.; Barakat, A.; El Baghdadi, M.; Oumenskou, H.; Aadraoui, M.; Karroum, L.A.; Hilali, A. GIS-based multi-criteria land suitability analysis for sustainable agriculture in the northeast area of Tadla plain (Morocco). J. Earth Syst. Sci. 2018, 127, 79. [CrossRef]

36. Platonov, A.; Noble, A.; Kuziev, R. Soil salinity mapping using multi-temporal satellite images in agricultural fields of syrdarya province of Uzbekistan Developments in Soil Salinity Assessment; Reclamation. Springer 2013, 112, 87-98.

37. Fan, X.; Liu, Y.; Tao, J.; Weng, Y. Soil salinity retrieval from advanced multi-spectral sensor with partial least square regression. Remote Sens. 2015, 7, 488-511. [CrossRef]

38. Allbed, A.; Kumar, L. Soil salinity mapping; monitoring in arid; semi-arid regions using remote sensing technology: A review. Adv. Remote Sens. 2013, 5, 43-52. [CrossRef]

39. Haith, D.A.; Tubbs, L.J. Watershed loading functions for nonpoint sources. J. Environ. Eng. Div. 1981, 107, 121-137.

40. Abuelaish, B.; Olmedo, M.T.C. Scenario of land use; land cover change in the Gaza Strip using remote sensing; GIS models. Arab. J. Geosci. 2016, 9, 274. [CrossRef]

41. Nasirian, H.; Irvine, K.; Sadeghi, S.M.T.; Mahvi, A.H.; Nazmara, S. Assessment of bed sediment metal contamination in the Shadegan; Hawr Al Azim wetlands, Iran. Environ. Monit. Assess. 2016, 188, 1-15. [CrossRef]

42. USGS. Landsat 8 Operational Land Imager (OLI); Thermal Infrared Sensor (TIRS); Frequently Asked Questions about the Landsat Missions; USGS. Science for a Changing World: Reston, VA, USA, 2016; pp. 1-6.

43. USGS. Using the USGS Landsat-8 Product. USGS. Science for a Changing World; Geological Survey in Vandenberg Air Force Base, California on an Atlas-V rocket in USA; U.S. Department of the Interior: Washington, DC, USA, 2013.

44. Muhaimeed, A.S. Status of Soil Information in Iraq, University of Baghdad College of Agriculture. Int. J. Digit. Earth 2014, 4, 434-443.

45. Omer, Tara Mohamed Anwar. Country Pasture/Forage Resource Profile. University of Sulaimaniyah. Available online: http://www.fao.org/ag/agp/AGPC/doc/Counprof/Iraq/Iraq.html (accessed on 13 December 2019).

46. Panagos, P.; Jones, A.; Bosco, C.; Senthil Kumar, P.S. European digital archive on soil maps (EuDASM): Preserving important soil data for public free access. Int. J. Digit. Earth 2011, 4, 434-443. [CrossRef]

47. Selvaradjou, S.-K.L.; Montanarella, O.; Spaargaren, D. Dent.European Digital Archive of Soil Maps (EuDASM)-Soil Maps of Asia DVD-ROM version. EUR 21823 EN. Off. Off. Publ. Eur. CommunitiesLuxemb. 2005, 7, 134-143.

48. Maurya, A.; Kesharwani, L.; Mishra, M.K. Analysis of Heavy Metal in Soil through Atomic Absorption Spectroscopy for Forensic Consideration. Int. J. Res. Appl. Sci. Eng. Technol. 2018, 6, 231-242. [CrossRef]

49. Addis, W.; Abebaw, A. Determination of heavy metal concentration in soils used for cultivation of Allium sativum L.(garlic) in East Gojjam Zone, Amhara Region, Ethiopia. Cogent Chem. 2017, 1, 1419422. [CrossRef]

50. Khattab, M.F.; Merkel, B.J. Application of Landsat 5; Landsat 7 images data for water quality mapping in Mosul Dam Lake, Northern Iraq. Arab. J. Geosci. 2014, 7, 3557-3573. [CrossRef]

51. Pour, A.B.; Hashim, M. Hydrothermal alteration mapping from Landsat- 8 data, SarCheshmeh copper mining district, south-eastern Islamic Republic of Iran. J. Taibah Univ. Sci. 2015, 9, 155-166. [CrossRef]

52. Guide, E.U.S. ENVI on-line software user's manual. ITT Visual Information Solutions 2008. Arab. J. Geosci. 2015, 8, 154-167.

(C) 2020 by the authors. Licensee MDPI, Basel, Switzerland. This article is an open access article distributed under the terms and conditions of the Creative Commons Attribution (CC BY) license (http://creativecommons.org/licenses/by/4.0/). 